\title{
William Frantz Public School: One School, One Century, Many Stories
}

\author{
Connie Lynn Schaffer \\ University of Nebraska at Omaha \\ cschaffer@unomaha.edu \\ Corine Meredith Brown \\ Rowan University \\ meredithc@rowan.edu \\ Meg White \\ Stockton University \\ meg.white@stockton.edu \\ Martha Graham Viator \\ Rowan University \\ mviator@rowan.edu
}

\begin{abstract}
William Frantz Public School (WFPS) in New Orleans, Louisiana, played a significant role in the story of desegregation in public K-12 education in the United States. This story began in 1960 when first-grader, Ruby Bridges, surrounded by federal marshals, climbed the steps to enroll as the school's first Black student. Yet many subsequent stories unfolded within WFPS and offer an opportunity to force an often-resisted discussion regarding systemic questions facing present-day United States public education — racial integration, accountability, and increasing support for charter schools. In this article, the story is told first in the context of WFPS and then is connected to parallels found in schools in New Orleans as well as other urban areas in the United States.
\end{abstract}

\section{Introduction}

Stories from American history are taught in thousands of public schools every year, but at times a school is a history lesson and a story in itself. Such is the case of William Frantz Public School (WFPS), an elementary school in the Upper Ninth Ward of New Orleans. The nearly centurylong story of WFPS includes a very distinct chapter captured in American history textbooks, the Civil Rights Movement of the 1960s. However, WFPS epitomizes many contemporary lesserknown stories within public schools in the United States, stories which deeply challenge the vision of Horace Mann, the noted patriarch of American public education. Mann envisioned a populace educated in publicly supported institutions in which children from all classes are taught by well-trained teachers. WFPS serves as a harbinger of what happens when social, political, and economic forces push public education to the margins. Yet hope remains, despite the all-toocommon marginalizing and demeaning of public education further complicated by unfathomable challenges. The WFPS building still stands with the descriptor "Public School" permanently cast 
in a cement façade over the main entry, symbolizing that United States public education can weather literal and figurative storms, but only if the public demands it.

The richness and importance of the WFPS story, as representative of American public schools, deserves telling. To be clear, the viewpoint presented here is not critical of the WFPS teachers or its students and their families, but of the systems within which they have been asked to teach and learn. The individual story of WFPS offers an opportunity to examine long-standing questions facing United States public education regarding racial integration, accountability, and increasing support for charter schools. The story here is told first in the context of WFPS and then connected to parallels found in New Orleans as well as other United States urban public schools.

\section{Quiet Beginning}

Like many schools built during the Great Depression, WFPS was constructed to accommodate a rapidly growing urban population. The Orleans Parish School Board (OPSB) built WFPS in 1937 at the same time that 500 public housing units were being constructed in an area known as the Florida neighborhood of the Upper Ninth Ward. During World War II, housing in the Florida neighborhood was designated for white war-time workers and after the war designated for white veterans (Matsumaru, 2011). As in much of the United States at the time, the school and its surrounding neighborhood were, by design of city planners and often at the direction of state and local law, racially segregated (Massey \& Denton, 1993).

Johnson C. Lockett Elementary, the WFPS counterpart for Black children who lived in the Upper Ninth Ward, was also built at this time, in the Desire housing area, a neighborhood primarily populated by Black residents. Remarkably similar in their outward appearances, less than one mile separated the two art deco buildings (Greater New Orleans Community Data Center, 2002). Despite the similar façades, learning opportunities for children attending the two schools differed dramatically, an inequality not unique to the city of New Orleans. Practices and policies of the time created the platoon system which exemplified this inequity within the district. The platoon system, openly acknowledged by Orleans Parish School Board, referred to the overcrowded buildings and shortened school days within New Orleans' Black schools.

This system prompted Ninth Ward parent, Wilfred S. Aubert, Jr. to demand better facilities for Black children; he filed suit against the school board in 1948 (Landphair, 1999).

In the early 1950s, as the United States Supreme Court agreed to hear the Brown v. Board of Education of Topeka case, another New Orleans parent filed suit against OPSB (Bush v. Orleans Parish School Bd., 1956). Oliver Bush's suit pushed beyond Aubert's demand for separate but equal facilities by calling for an end to racial segregation of Orleans Parish School District (OPSD) schools (Douglas, 2005; Landphair, 1999). This reflected the National Association for the Advancement of Colored People's legal approach to target the systemic racism represented in Jim Crow laws through litigation within the institution of education. In a series of legal maneuvers, Bush's original lawsuit was suspended then resurrected in 1957 at which time a panel of federal judges ruled the 1954 school segregation amendment to the Louisiana State Constitution to be unconstitutional. This was the first post-Brown ruling in the Deep South. Yet before integration would begin, it took three years and an additional court order from Judge J. 
Skelly Wright specifying a desegregation plan to begin in 1960 focusing on first grade students in New Orleans public schools (Douglas, 2005).

\section{Iconic Role}

November 1960. When the school year began in fall 1960, few people other than those living in the working-class Florida neighborhood recognized WFPS, and likely many of its white residents gave little thought to Black children prohibited from attending the school or the implications of racially segregated schools. By mid-November, the unassuming nature of WFPS was forever relegated to the past. In a much-delayed response to the court order, OPSB designated two all-white schools - WFPS and McDonogh No. 19-for integration. This forced WFPS to assume a new role in the limelight of the Civil Rights Movement and in the history of United States public education.

Both WFPS and McDonogh No. 19 were located in the much-neglected and economicallydeprived Ninth Ward, an area which "was always the last to get street lights, the last to get paved streets, and the last to receive myriad other city services which other sections were able to obtain more easily" (Crain \& Inger, 1966, p. 50). Some speculated WFPS was chosen because the working-class Ninth Ward neighborhood had much less political sway than other parts of the city and as such, was an easier choice for school board members who felt little connection to the area. Others speculated the choice was based on the assumption Black children would perform better and feel less inferior in the lower performing schools of the Ninth Ward (Reckdahl, 2010).

In a last minute effort to stave off desegregation, Louisiana declared a school holiday on the date integration was to begin. Although he supported segregation, the president of the New Orleans School Board, Lloyd Rittiner, refused to close the city's schools despite Louisiana Governor James Houston Davis' threat to jail him if he did not close them (Reckdahl, 2010). On what many expected would be a school holiday, WFPS opened its doors to Ruby Bridges as well as itself to the scrutiny of the world on November 14, 1960.

In the Spotlight. Regardless of the motivation behind the choice of schools and despite desperate measures to prevent integration, WFPS suddenly transformed from a nondescript neighborhood school to being in the center of the international spotlight when first grader Ruby Bridges became the first Black child to attend WFPS. Images of the building appeared in newspapers and on televisions around the world as the school was center stage in what would be described as the New Orleans School Crisis (Louisiana State Advisory Committee to the United States Commission on Civil Rights, 1961). Time Magazine declared November 14 as "D-day in New Orleans" reporting racism had "squared off against the push of sociological change" (Time, $1960,21)$. Widely recognized writers chronicled the events. John Steinbeck, in New Orleans at the time, described vitriolic protests led by white women, known as the cheerleaders, who surrounded and taunted Bridges as she arrived at the school (Landphair, 1999; Steinbeck, 1962). Writing for the New Yorker, John Updike (1960), described the women as "segregationist banshees" who screamed obscenities at children (p. 43).

Norman Rockwell further immortalized the ugliness of the events in the famous 1963 painting, The Problem We All Live With (1964) which later appeared as a two-page centerfold in Look 
magazine (Rockwell's artwork would re-enter the American story in 2011 when President Obama chose to display the painting just outside the Oval Office [Norman Rockwell Museum, 2018].)

Nearly 40 years after Bridges entered WFPS, two children's books and a made-for-television film introduced the notoriety and distinct role of the school to a new generation. Pulitzer Prize winner Robert Coles (1995) published the book, The Story of Ruby Bridges, and Bridges (1999) told her own story in the book Through My Eyes. Disney created its version of the story in a 1998 movie, Ruby Bridges (Hopkins \& Palcy, 1998), which received considerable media attention. An LA Times review urged people to watch the movie (Miller, 1998), and they did. In its daily publication, Variety reported the movie "won its slot in kids, teens and all key female demos" (Bierbaum, 1998, p. 1).

The Danger. Along with the books and movie, attention continued to be focused on WFPS and the events of 1960. Over the years, particularly at milestone anniversary dates of the iconic 1960 events, Bridges as well as her classmates, federal marshal escorts, her first-grade teacher Barbara Henry, and leaders in New Orleans shared their experiences in the city, state, and national media. The retelling of individual stories is interesting, important, and at times inspiring. Certainly, the "sheer magnitude of the historical obstacles caused by the racial climate of New Orleans, and the tales of teachers, community members, students, and school administrators who worked long and hard to combat racism, should not be lost” (Kennedy, 2016, p. 20).

However, these recollections are not enough and should not be separated from the broader story. To do so risks the danger of minimizing powerful, systemic social and political forces that sanctioned racially segregated housing and schools, situated these practices as acceptable and even beneficial to society, allowed court orders to be repeatedly delayed in an effort to maintain them, and revealed deep-seated racism in the hatred-laden protest that took place outside of WFPS (Kennedy, 2016; Ladson-Billings, 2006). The systemic issues represented in this early chapter of WFPS remain unresolved and continue to influence WFPS and public education throughout the United States.

In the case of WFPS, its place in the spotlight of the Civil Rights Movement eventually earned the building a listing on the National Register of Historic Places in April 2005, the timing of which would prove more fortuitous than anyone could possibly have imagined (National Register of Historic Places, 2005). The spotlight of the 1960s, of course, dimmed over time; yet the story of WFPS continued. Not only had it served as a fortress for Bridges and represented a key school desegregation battleground of the 1960s, in subsequent decades the great narrative of public education - its foibles, its fortitude, and its fate - unfolded in WFPS. These chapters in the WFPS story appeared primarily in local media rather than in the international press. They were not dramatically chronicled, nor were they recounted in paintings, books, or movies. However, in these lesser-known chapters the story of WFPS parallels those of many other United States public schools. What happened to WFPS since 1960 exemplifies many aspects of what has happened in urban schools throughout the United States.

Past policies, such as separate but equal, which segregated WFPS and other American schools have been overturned but replaced with contemporary policies such as school choice. Policies Journal of Contemporary Issues in Education, 2018, 13(2), pp. 21-36 
and legislation within a majority of states in the United States support varied forms of school choice including charter schools, voucher programs, tuition tax-credits, and open enrollment either within a district or between districts (Hoxby, 2018; Whitehurst, 2017). In a study examining the largest school districts in the United States, the Brookings Institute found "unconstrained school choice leads to more segregated schools" and "charter schools, which are always schools of choice, have a substantially higher racial imbalance relative to their catchment area than traditional schools" (Whitehurst, 2017, p. 7-8). This story of school choice evolved over the decades following Bridges' enrollment at WFPS.

\section{More to the Story}

School Resegregation via White Flight. To some, Bridges' enrollment at WFPS signaled an end to school segregation in New Orleans. Nothing could be farther from the truth. It was, in fact, the beginning of a repackaged school segregation. While the immediate reaction to Bridges' enrollment was an eruption of overt protests outside the doors of WFPS, a less public - but more long-lasting - backlash ensued. White parents withdrew their children from WFPS, and the exodus of these students began immediately (Louisiana State Advisory Committee to the United States Commission on Civil Rights, 1961; Mullener, 1993; Wieder, 1987). United States newspapers "carried a running box score" of the number of white students attending WFPS (Crain \& Inger, 1966, p. 76).

In addition to the existing and quite expansive Catholic school system in New Orleans, other private schools such as the Arabi Annex located in a former Ford Motor plant in nearby St. Bernard Parish, opened within days of Bridges' enrollment at WFPS (Campanella, 2014). Contributions from the infamous and influential political boss, Leander Perez, and the White Citizens Council along with subsidies from the State of Louisiana provided support for Arabi and other private schools such as the Ninth Ward Cooperative School (Baker, 1996; Jeansonne, 1977; Landphair, 1999; Wells, 2004). In addition to providing the private school subsidies, the State of Louisiana cut off funding to OPSD. As a result, OPSD teachers went unpaid in what was hailed as a time of crisis in New Orleans (Baker, 1996, Crain \& Inger, 1966; Louisiana State Advisory Committee to the United States Commission on Civil Rights, 1961; Time, 1960).

In New Orleans, school choice had been expanded, hope of desegregation had dimmed, and resegregation had begun, all within a matter of days. Systematic integration of New Orleans' public schools progressed at a frustratingly slow rate and was exacerbated by a steady egress of white students to non-public schools supported by discriminatory school funding policies (Hall, 1970). Subsidized by state tuition grants, white parents withdrew their children from public schools and enrolled them in private, non-Catholic schools (Mullener, 1993). White families founded these segregationist academies to avoid sending their children to the now desegregated public schools. Segregationist academies exploded across the United States with enrollments growing from 25,000 in 1966 to 535,000 by 1972 (Lowry, 1973). Remarkably, these schools with overtly racist enrollment policies remained tax-exempt until 1970 when the United States Internal Revenue Service determined it could "no longer legally justify allowing tax-exempt status to private schools which practice racial discrimination" (Hall, 1970, p. 2). 
Between 1970 and 1979 white student enrollment fell 71\% in New Orleans public schools, dramatically changing the student demographic (Cowen Institute for Public Education Initiatives, 2008; Orfield, 1983). Like many schools in the city, WFPS became a majority African-American school (Rasheed, 2006) in a majority African-American school district. In addition to the movement of white families, Black middle class families also moved from the Upper Ninth Ward into suburban areas, resulting in an increasingly Black and increasingly poor student population in OPSD (Carr, 2013; Johnson, 2008).

While it may be shocking that this phenomenon began before WFPS left the headlines, the extent to which this pattern materialized in urban schools across the United States is perhaps even more disturbing. As urban school districts throughout the country initiated integration efforts, the schools "usually became virtually all-minority in a few years as did the neighborhoods" (Orfield, 2001, p. 7). White and middle class flight occurred in cities across the country (Carr, 2013; Casserly, 2006). Between 1968 and 1980, white student enrollment declined approximately 45\% in New York City, 63\% in Boston, 86\% in Atlanta, 63\% in Houston, 77\% in Detroit, 62\% in Chicago, 63\% in Los Angeles, and 40\% in San Diego (Orfield, 1983).

School Accountability. As white and overall student enrollment declined in OPSD, so too did the revenue needed to support the district. This led to inadequate resources to maintain facilities and support instruction (Casserly, 2006). By the 1980s, WFPS needed extensive, long-overdue repairs. Conditions were so dire the building was temporarily closed in order to remove asbestos, repair termite damage, and address electrical and air conditioning needs (Nabonne, 1992).

Disrepair was not its only challenge. WFPS also faced increased scrutiny regarding the academic performance of its students. During the 1990s, the Louisiana Department of Education began issuing performance scores to K-8 public schools. In 1998-1999, WFPS scored in the lowest performance category (Louisiana Department of Education, 1999). In that same decade, Louisiana passed two laws, Act 192 in 1995 and Act 477 in 1999, authorizing charter schools, reflecting a growing trend across the country (Garda, 2011).

In addition to state accountability measures, WFPS, like most public schools, grappled with the enactment and impact of the federal No Child Left Behind (2002) legislation and its harsh consequences for what were deemed to be low performing schools. After some initial improvements in its ratings, WFPS's performance rating slipped to Louisiana's lowest possible rating, "Academically Unacceptable", during the 2004-2005 school year (Louisiana Department of Education, 2005). OPSD determined the school should be closed. A New Orleans Times Picayune op-ed, pleaded for reconsideration, “Changes are needed, but due to Frantz's historical significance, the building should never become vacant. It should remain functional in the same capacity and with the same intent that Ruby Bridges' parents had for her: as a place where eager little minds can receive a quality education" (Corley, 2005, p. 4).

WFPS was not alone. Louisiana repeatedly disinvested in the OPSD following the early 1960s, leaving the district woefully short of funding and unable to adequately maintain school facilities (Casserly, 2006). For example, in 1993 the district had "less than \$1 million for school construction and repairs even though it needed an estimated $\$ 475$ million to simply ensure all schools were air-conditioned and met safety requirements" (Cowen Institute for Public

Journal of Contemporary Issues in Education, 2018, 13(2), pp . 21-36 
Education Initiatives, 2015 - no page). In addition, due to the migration of middle class families from New Orleans, OPSD students were increasingly from poor families (Carr, 2013; Johnson, 2008). Financial scandal exacerbated Louisiana's inadequate funding. Several Orleans Parish School Board members as well as district administrators were accused of mishandling, if not embezzling, millions of dollars of state and federal funds, resulting in multiple resignations and indictments of district leaders (Casserly, 2006; Mirón \& Lauria, 2015).

In 1999, 47 New Orleans schools were deemed "Academically Unacceptable" making a potential one-third of OPSD students eligible to choose to attend a different school (Vaishnav \& Alpert, 1999). By 2003, the State Board "declared Orleans Parish School Board in academic crisis" (Johnson, 2008, p. 432-433), paving the way for the State Board of Education to take over the district's failing schools (Garda, 2010). Educationally, "the children of New Orleans were isolated racially, economically, academically, and politically in public schools that were financed inadequately, maintained poorly, and governed ineptly" (Casserly, 2006, p. 197). In response to the situation, the State Board of Education established the Recovery School District and took control of five OPSD schools including WFPS (Thevenot, 2005).

However, while many schools in OPSD were performing below state averages, they had made considerable academic progress (Buras, 2011). According to a 2006 interview with the President of the United Teachers of New Orleans, Dr. Brenda Mitchell, 93 OPSD schools had made growth over the past five years and 88 had met the Adequate Yearly Progress mandated in No Child Left Behind (Perry, 2006).

In the period between 1990 and the early 2000s, the political rhetoric in the United States created a perception of failing schools and a "belief that America's public schools were in an arc of decline" (Ravitch, 2013, p. 39). In the name of accountability, the federal and many state governments passed sweeping laws and enacted onerous policies related to public schools. These measures often imposed judgments on schools with associated rewards and sanctions for good or poor performance (Ravitch, 2013; U.S. Department of Education, National Center for Education Statistics, 2003). Much of this effort was misdirected as it failed to address years of economic policies that led to financial indifference if not neglect of urban schools (Casserly, 2006; Maxwell, 2007) as well as the fundamental social issues related to increased concentrations of poverty in urban neighborhoods (Squires \& Kubrin, 2005).

Factors associated with poverty, such as inadequate health care, unhealthy diets, and substandard housing impacted a large percentage of children in urban school districts (Carter \& Welner, 2013). This meant, along with concerns related to segregation, educational equity was also an issue. Urban schools, with very limited resources and increasing numbers of children from lowincome households, were expected to meet the many needs indicative of their students. Systemic refusal to acknowledge very germane educational issues related to poverty and racism as well as inadequate funding and resources for schools that disproportionately faced these challenges represented the widespread, "inter-locking and ill-fated realities" (Johnson, 2008, p. 431) of the failure to support urban public schools in the United States (Darling-Hammond, 2013).

Hurricane Katrina. The story of WFPS includes a second unique chapter, the events of 2005. On June 8, 2005, WFPS celebrated its seminal role in American civil rights when it was given a Journal of Contemporary Issues in Education, 2018, 13(2), pp. 21-36 
listing on the National Register of Historic Places (National Register of Historic Places, 2005). Although the designation protected the structure, the educational programs housed in the building remained embroiled in the turmoil around its announced closure. This, however, was barely a squall on the horizon compared to what lay ahead for WFPS and all of New Orleans. Two weeks into the school year, on August 29, 2005, WFPS stood amidst the fury of nature unleashed by Hurricane Katrina and the subsequent stumbling response of a country coming face-to-face with the shortcomings of the previous decades.

The storm was particularly lethal and ruthless in the Upper and Lower Ninth Wards. WFPS sustained significant damage and was deemed unfit for use. The storm caused substantial roof damage; additionally, mold caused by heavy flooding left "only the carcass of the historic structure standing" (Billes \& Kravet, 2008, p. 117). Due to the efforts of Bridges and others just weeks before Hurricane Katrina, WFPS was listed on the National Register of Historic Places. This designation provided WFPS a unique protection from the fate of many buildings in the city; thus, making it one of few structures to survive the severe storm, prolonged flooding, looting, and vandalism, as well as post-Katrina recovery and reconstruction policies.

Although slated for a $\$ 23.5$ million renovation funded by the Federal Emergency Management Association (Billes \& Kravet, 2008; Chang, 2010), there was little need for expediency to make WFPS safe for occupancy. Few students and teachers remained in the city, and for several months the United States military enforced a no-return policy in the uninhabitable Ninth Ward (Dingerson, 2007). Groundbreaking for WFPS renovations did not begin until November 2010, a full five years after Hurricane (Recovery School District, 2010).

Hurricane Katrina devastated most New Orleans schools, causing more than $\$ 800$ million in damages, with fewer than 20 of the approximately 120 OPSD buildings remaining usable (Garda, 2011). The storm largely destroyed state and local tax bases, nearly eradicating district revenue sources (Cohen, 2006). Enrollment plummeted as Katrina displaced over 60,000 schoolaged children, many of whom permanently moved out of OPSD (Garda, 2010). Just over two weeks after Katrina, district officials cited these low enrollments as the reason for placing approximately 4,500 teachers on unpaid disaster leave (Dingerson, 2007; Perry, 2006).

Within three months, the State of Louisiana transferred responsibility for most OPSD schools to the already existing Recovery School District, despite the fact that more than half of the New Orleans legislators opposed the move (Dingerson, 2007, United Teachers of New Orleans, 2006). By January 2006, the school board voted to terminate the contracts of all former teachers. The American Federation of Teachers which was demanding OPSD open more schools garnered a brief stay, but by March the termination of salary and benefits took effect (Dingerson, 2007; Perry, 2006). Demoralized and faced with demeaning and frustrating hurdles put in place by the Recovery School District, many former OPSD teachers retired or found employment in other districts, thus draining New Orleans of experienced teachers (Johnson, 2008; Mitchell, 2015).

Suffice it to say, it is impossible to do more than speculate what may have transpired had there been no Hurricane Katrina or to know precisely how the catastrophe impacted WFPS or OPSD. Striking parallels to the 1960s chapter of WFPS exist. While Bridges, a young Black girl was the target of overt racism in 1960, Black teachers were the target of a more subtle and covert racism 
as they represented a majority of the OPSD teachers fired in 2006 (Dingerson, 2007; LadsonBilling, 2006; Lincove, Barrett, \& Strunk, 2017; Mitchell, 2015; Perry, 2006). As in 1960, OPSD teachers went unpaid as a result of systems that failed to adequately respond to a crisis. Furthermore, just as the resegregation efforts were an immediate response to Bridges' enrollment at WFPS, efforts to privatize OPSD schools following Katrina happened at a dizzying pace and outside the limelight of the recovery efforts within New Orleans.

Charter Schools. Before Hurricane Katrina, the structure and governance of OPSD resembled that of most United States urban districts (Harris, 2013). The massive devastation caused by the hurricane and the ensuing rapid-fire policy decisions at the state and district levels disrupted every facet of education and created gaping voids in the educational infrastructure, leadership, and workforce within New Orleans. Charter school supporters seized the opportunity and quickly rushed into the space, expanding their footprint across New Orleans (Garda, 2011). WFPS was not exempt. While the William Frantz building still stood, the public school housed within it would cease to exist.

Officials searched for a charter school to occupy the William Frantz building. In 2010, Bridges resurfaced, announcing she was applying to open a charter within the William Frantz building. She wanted the charter to focus on community service and social justice (Dequine, 2010; Strachan, 2010). Her vision did not come to fruition. Ultimately, the Recovery School District approved a charter for Benjamin Mays Prep to move into the William Frantz building (Dreilinger, 2014). After the Benjamin Mays charter failed, the Recovery School District selected Akili Academy, one of three Crescent City Charter Schools, to replace it. Akili, operational since 2008 , was originally granted a charter in a different location. However, to make room for a KIPP charter school, the Recovery School District relocated Akili into the William Frantz building (Dreilinger, 2014). In addition to the federal funding for renovations, the Akili Academy charter school received \$250,000 from the Walton Family Foundation and opened its doors within the William Frantz building in September 2013 (Layton, 2014).

What happened in the William Frantz building happened elsewhere in New Orleans. The city may have been significantly devoid of habitable buildings, school students, and teachers but was flush with financial and policy support for charter schools. What occurred in the months following Katrina amounted to an "educational land grab" (Au et al., 2006, p. 5) and disaster capitalism (Klein, 2007). Within a month of the storm, the federal government appropriated nearly \$21 million to open charter schools in New Orleans and another \$24 million would follow six months later (Dingerson, 2007).

State officials acted quickly, changing and creating policies which permitted charter schools to bypass standard application regulations. The city formed the Bring New Orleans Back Commission which advocated for significantly and quickly increasing the number of charter schools within the district as an expedited means to restarting public education in New Orleans (United Teachers of New Orleans, 2006). Dubbed as innovations, the policies allowed for selective student enrollment as well as the discontinuation of collective bargaining and tenure for teachers (Buras, 2011). Charter schools overtook PK-12 education in New Orleans. By January 2006, approximately six months after Katrina, 17 PK-12 schools were open in the city, 14 of 
which were charters. By 2015, charter schools held $90 \%$ of the educational market share in New Orleans (Peters, 2015).

The startling pace of charter schools, often presented under broader monikers such as 'school reform' and 'school choice', impacted education in New Orleans in many ways. In addition to the termination of thousands of educators which demoralized the teaching force, the demographics of the New Orleans teachers significantly shifted. The percentage of Black teachers in New Orleans' schools, once a point of pride when compared to other United States cities, dropped dramatically, and the increasingly white teacher workforce had less experience and fewer local ties to New Orleans (Barrett \& Harris, 2015). For families, school choice materialized as a difficult to understand and navigate maze (Adelman-Cannon, 2006; Kretchmar \& Sondel, 2014; Ritea \& Nelson, 2006). A statement from one parent "who bemoaned the fact that she couldn't just send her child to a competent district school down the street" (AdelmanCannon, 2006, p. 27) and the Associated Press reporting that understanding "who's in charge of the (New Orleans) schools these days requires a scorecard" (Cohen, 2006, no page) depict unnerving similarities to 1960 .

Certainly, the post-Katrina context in New Orleans called for an expedited and large-scale response. However, acknowledgement of the distinct nature of the response should not distract from the fact that opportunistic charter advocates seized the chance to use New Orleans schools as a "grand experiment in urban education" (Ritea \& Nelson, 2006, p. 1) and present it as "a proof of concept, a beacon and a symbol for school reform" (Harris, 2013, p. 10). In fact, this is precisely what occurred.

In September 2017, Hurricane Maria hit Puerto Rico killing thousands and damaging countless structures including hundreds of school buildings. In the aftermath of the storm, the island's student population declined by 17 percent (Aronoff, 2018). In response, Puerto Rico's Secretary of Education, Julia Keleher identified Hurricane Katrina and New Orleans as a "point of reference" and described the disaster in Puerto Rico as an "opportunity to create new, better schools" (Keleher, 2017). Similar to schools in New Orleans prior to Katrina, Puerto Rico's public schools also struggled prior to Maria. In 2016, less than half of Puerto Rico's public school students were considered proficient in reading, math, or science (United States Department of Education, 2017). Also similar to New Orleans, student achievement scores in Puerto Rico were not the only concern. Due to crippling debt, school budgets had been slashed resulting in outdated school facilities (Vicens, 2018; Williams Walsh, 2017) and in 2016, nearly 60 percent of Puerto Rico's children lived in poverty (Annie E Casey Foundation, 2016).

In the months following the storm, the Commonwealth of Puerto Rico, working in conjunction with the Fiscal Oversight and Management Board (the federal agency put in place prior to Maria), cited declining enrollments as the reason to close over 250 public school buildings in Puerto Rico (Aronoff, 2018). Keleher, along with Governor Ricardo Rosselló Nevares, outlined what they saw as a "great change” to Puerto Rico's schools (Rosselló Nevares, 2018). The socalled great change introduced charter schools and included "educational vouchers and free selection of schools". 
To exempt the charter movement from careful examination represents an affront to all public schools but particularly to urban schools. The trend to "reengineer" (Buras, 2011, p. 313) United States public education through the charter movement disproportionately takes place in urban schools and with an over-representation of Black students where many perceive schools to be failing - even though there is conflicting evidence charter schools improve the learning outcomes for students (Chapman \& Donnor, 2015).

While the evidence related to student performance in charter schools across the United States is widely debated, systemic issues which contribute to resegregation in charter schools is much less discussed. School choice assertions undergirding the charter movement may be presented and appear as race-neutral educational policy but can actually lead to segregated schools (Straus \& Lemieux, 2016). It is because of persistent color blindness, that Americans fail to recognize deeply entrenched racist and prejudicial systems in schools and other institutions (Alexander, 2012; Carr, 2013; Thomas, 2013). The current acceptance of the racism represented in resegregated schools remains strong, sobering and deeply saddening.

\section{Conclusion}

Telling the story of public schools through the lens of a single school widely recognized throughout the United States makes it more difficult for Americans to dismiss a story that can be unsettling to hear. As WFPS faced the most difficult of circumstances, so too must Americans. Difficult issues face public education not only in New Orleans, but across the country.

Although Horace Mann (1867), architect of United States public education, once envisioned education as "our only political safety" and "outside of this ark all is deluge" (p. 220), Americans must now answer a number of fundamental questions. Can public schools ever be the haven for the democracy Mann envisioned? Will public schools be a place in which racial integration can be advanced in the United States? Does America have the determination to demand accountability not only of public schools but equally as important, the systems that are supposed to support it?

Remarkably, the William Frantz building remains standing in the Upper Ninth Ward of New Orleans. The original engraving, 'William Frantz Public School' cast in 1937 has come to symbolize the safety the school provided to Bridges in 1960 and the resilient survival from the deluge of Katrina in 2005. The words 'William Frantz Public School' remain a prominent feature on this landmark. Regrettably, it no longer houses a public school. Yet hopefully, its story will inspire Americans now and in the future to fully support racially integrated schools and adequately fund public education; and thus, public education might someday protect democracy. 


\section{References}

Adelman-Cannon, L. E. (2006). Into the flood and out again: A year in the life of a New Orleans schoolteacher. Rethinking Schools, 21(1), 25-27.

Alexander, M. (2012). The new Jim Crow. New York: The New Press.

Annie E. Casey Foundation. (2016). Child population below the poverty line [Kids Count Data Center and data tables]. Available from Annie E. Casey Foundation web site: https://www.aecf.org/

Aronoff, K. (2018). A hurricane in the classroom: Inside the schools ensnared in Puerto Rico's privatization fever and how its teachers are fighting back. Rethinking Schools, 32(4), 2028.

Au, W., Burant, T., Bigelow, B., Christensen, L., Levine, D., Karp, S., Miller, L.,...Walters, S. (2006). Educational land grab. Rethinking Schools, 21(1), 5-6.

Barrett, N., \& Harris, D.N. (2015). Significant changes in the New Orleans teacher workforce. New Orleans, LA: Education Research Alliance for New Orleans.

Baker, L. (1996). The second battle of New Orleans: The hundred-year struggle to integrate the schools. New York, NY: Harper Collins Publishers, Inc.

Bierbaum, T. (1998, January 20). Golden ratings for the Globes. Daily Variety, p. 1. Retrieved from https://advance-lexis-com.leo.lib.unomaha.edu/api/permalink/f6ac7ef8-625849ea-9ebc-a40ef51ddcc5/?context $=1516831$

Billes, G. W., \& Kravet, R. S. (2008, November/December). Revisiting New Orleans, Urban Land: The Magazine of the Urban Land Institute, 114-177.R.

Bridges, R. (1999). Through my eyes. New York, NY: Scholastic.

Buras, K. L. (2011). Race, charter schools, and conscious capitalism: On the spatial politics of whiteness as property (and the unconscionable assault on black New Orleans). Harvard Educational Review, 81(2), 296-331.

Bush v. Orleans Parish School Bd., 138 F. Supp. 337 (E.D. La 1956), aff'd 242 F.2d 156 (5th Cir. 1957), cert. denied, 354 U.S. 921, 7 S.Ct. 1380, 1 L.Ed.2d 1436 (1957).

Campanella, R. (2014, November 8). Arabi assembly plant represented a little bit of the Motor City in the Crescent City. New Orleans Times-Picayune, p. A06.

Carr, S. (2013). Hope against hope: Three schools, one city, and the struggle to educate America's children. New York, NY: Bloomsbury Press.

Carter, P. L., \& Welner, K. G. (Eds.). (2013). Closing the opportunity gap: What America must do to give every child an even chance. New York, NY: Oxford Press.

Casserly, M. (2006). Double jeopardy: Public education in New Orleans before and after the storm. In C.W. Hartman \& G.D. Squires (Eds.), There is no such things as a natural disaster: Race, class, and Hurricane Katrina (pp. 197-214). New York, NY: Routledge.

Chang, C. (2010, December 20). Construction boom begins for N.O. schools - Facilities are getting a major overhaul. New Orleans Times-Picayune, p. A01.

Chapman, T. K., \& Donnor, J. K. (2015). Critical race theory and the proliferation of U.S. charter schools. Equity \& Excellence in Education, 48(1), 137-157. https://doi.org/10.1080/10665684.2015.991670

Cohen, S. (2006, March 4). New Orleans' troubled public schools called Katrina's 'silver lining'. Associated Press, no page.

Coles, R. (1995). The story of Ruby Bridges. New York, NY: Scholastic.

Journal of Contemporary Issues in Education, 2018, 13(2), pp. 21-36 
Corley, D. (2005, June 6). School is a piece of history. New Orleans Times-Picayune, p. 04.

Cowen Institute for Public Education Initiatives (2008). The state of public education in New Orleans, 2008 Report. New Orleans, LA: Author. Retrieved from https://www.bcg.com/documents/file23272.pdf

Cowen Institute for Public Education Initiatives (2015). An interactive timeline of New Orleans public education: 1718-present. New Orleans, LA: Author. Retrieved June 22, 2018 from http://www.speno2015.com/timeline.html

Crain, R. L., \& Inger, M. (1966). School desegregation in New Orleans: A comparative study of The failure of social control, Report No. 110-B, Chicago, IL: National Opinion Research Center, University of Chicago.

Darling-Hammond, L. (2013). Inequality and school resources: What it will take to close the opportunity gap. In P. L. Carter \& K. G. Welner (Eds.), Closing the opportunity gap: What America must do to give every child an even chance (pp. 77-97). New York, NY: Oxford Press.

Dequine, K. (2010, September 26). Civil rights pioneer recalls school days: Ruby Bridges still fights racism. New Orleans Times-Picayune, p. F01.

Dingerson, L. (2007). Dismantling a community timeline. The High School Journal, 90(2), 8-15. Douglas, D. M. (2005). Bush v. New Orleans Parish School Board and the desegregation of New Orleans schools, Prepared for inclusion in the project Federal Trials and Great Debates in United States History, Federal Judicial Center.

Dreilinger, D. (2014, August 3). School change has become the new normal: A shift can set off a chain reaction. New Orleans Times-Picayune, p. A11.

Garda, R. (2011). The politics of education reform: Lessons from New Orleans. Journal of Law \& Education, 40(1), 57-103.

Greater New Orleans Community Data Center (2002). Florida area neighborhood snapshot, Retrieved on May 6, 2018 from http://www.datacenterresearch.org/prekatrina/orleans/7/17/snapshot.html

Hall, I. (July 18, 1970). IRS sets the rules. Pittsburgh Courier, p. 2.

Harris, D. N. (2013). The post-Katrina New Orleans school reforms: Implications for national school reform and the role of government. Remarks to University of Michigan Ford School of Public Policy, October 4, 2013, New Orleans, LA: Education Research Alliance for New Orleans, Retrieved from https://educationresearchalliancenola.org/files/publications/UM-Speech-on-NewOrleans3.pdf

Hopkins, A., \& Palcy, E. (Producers), \& Palcy, E. (Director). (1998). Ruby Bridges [Motion Picture]. United States: Disney Studios.

Hoxby, C. M. (September 24, 2018). The economics of school reform. Retrieved from http://www.nber.org/reporter/spring98/hoxby_spring98.html

Jeansonne, G. (1977). Leander Perez: Boss of the delta. Baton Rouge, LA: Louisiana State University Press.

Johnson, K. A. (2008). Hope for an uncertain future: Recovery and rebuilding efforts in New Orleans's schools. Urban Education, 43(4), 421-444. http://dx.doi.org/10.1177/0042085908315940

Keleher, J. [SecEducacionPR]. (2017, October 26). Sharing info on Katrina as a point of reference; we should not underestimate the damage or the opportunity to create new,

Journal of Contemporary Issues in Education, 2018, 13(2), pp. 21-36 
better schools [Tweet]. Retrieved from

https://twitter.com/seceducacionpr/status/923724280885661696

Kennedy, A. (2016). The history of public education in New Orleans still matters. History

Faculty Publications. Paper 5. New Orleans, LA: The University of New Orleans.

Retrieved from http://scholarworks.uno.edu/hist_facpubs/5

Klein, N. (2007). The shock doctrine: The rise of disaster capitalism. New York, NY: Picador.

Kretchmar, K., \& Sondel, B. (2014). Organizing resistance to Teach for America. Rethinking Schools, 28(3), 32-37.

Ladson-Billings, G. (2006). Now they are wet: Hurricane Katrina as a metaphor for social and educational neglect. Voices in Urban Education, 10, 5-10.

Landphair, J. (1999). Sewerage, sidewalks, and schools: The New Orleans Ninth Ward and public school desegregation. Louisiana History: The Journal of the Louisiana Historical Association, 40(1), 35-62.

Layton, L. (2014, May 28). In New Orleans, major school district closes traditional public schools for good. Washington Post, no page.

Lincove, J.A., Barrett, N., \& Strunk, K.O. (2017). Did the teachers dismissed after Hurricane Katrina return to public education? New Orleans, LA: Education Research Alliance for New Orleans.

Louisiana Department of Education. (1999). The Louisiana school report card. Retrieved from https://www.louisianabelieves.com/data/files/reportcards/1999/Districts/036.pdf

Louisiana Department of Education. (2005). The Louisiana school report card. Retrieved from https://www.louisianabelieves.com/data/files/reportcards/2005/detailed/2005_DPR_036.p df

Louisiana State Advisory Committee to the United States Commission on Civil Rights (1961). The New Orleans school crisis, Washington, DC: US Government Printing Office.

Lowry, M. (1973). Schools in transition. Annals of the Association of American Geographers, 63(2), 167-180. https://doi.org/10.1111/j.1467-8306.1973.tb00917.x

Mann, H. (1867). Thoughts selected from the writings of Horace Mann. Boston: H.B. Fuller. Retrieved from https://hdl.handle.net/2027/uc2.ark:/13960/t7zk5kn2p?urlappend=\%3Bseq=226

Massey, D., \& Denton, N. (1993). American apartheid: Segregation and the making of the underclass. Cambridge, Mass.: Harvard University Press.

Matsumaru, T. (2011). Defending Desire: Resident activists in New Orleans Desire Housing Project, 1956-1980, University of New Orleans Theses and Dissertations. Paper 449.

Maxwell, L. A. (2007). Up from the ruins. Education Week, 27(6), 27-30.

Middleton, T. (2011). Norman Rockwell's The problem we all live with: Teaching Bush v. Orleans Parish School Board. Social Education, (75)6, 329-333.

Miller, D. H. (1998, January 17). Ruby Bridges looks at a hateful world. Los Angeles Times, no page. Retrieved from http://articles.latimes.com/1998/jan/17/entertainment/ca-9099

Mirón, L., \& Lauria, M. (2015). Up to higher ground: School choice and the promises of democracy post-2005. In L. Mirón, B. R. Beabout, \& J. L. Boselovic (Eds.), Only in New Orleans: School choice and equity post-Hurricane Katrina (pp. 3-15). Rotterdam, The Netherlands: Sense Publishers.

Mitchell, C. (2015). Death of my career: What happened to all of New Orleans' veteran Black teachers. Education Week, 35(1), 19-21. 
Mullener, E. (1993, June 16). Order to integrate schools shakes city to its core. New Orleans Times-Picayune, p. A16.

Nabonne, R. (1992, October 13). School board's leases costing \$47,000 a month. New Orleans Times-Picayune, p. B1.

National Register of Historic Places, (2005). Frantz, William School, New Orleans, Orleans County, Louisiana, National Register \#0500057. Retrieved on May 8, 2018 from https://catalog.archives.gov/id/73974310

No Child Left Behind Act of 2002, P.L. 107-110, 20 U.S.C. § 6319 (2002).

Norman Rockwell Museum (2018). Iconic 1963 painting on loan from permanent collection of Norman Rockwell Museum, July 5, 2011. Retrieved on June 14, 2018 from https://www.nrm.org/2011/05/norman-rockwells-the-problem-we-all-live-with-to-beexhibited-at-the-white-house/

Orfield, G. (1983). Public school desegregation in the United States, 1968-1980. Washington, DC: Joint Center for Political Studies.

Orfield, G. (2001). Schools more separate: Consequences of a decade of resegregation. Cambridge, MA: Harvard Civil Rights Project.

Peters, M. A. (2015). Foreword: Katrina, neoliberalism, and the undermining of public education. In L. Mirón, B. R. Beabout, \& J. L. Boselovic (Eds.), Only in New Orleans: School choice and equity post-Hurricane Katrina (pp. ix-x). Rotterdam, The Netherlands: Sense Publishers.

Perry, T. (2006). The plight of the education systems - post Hurricane Katrina: An interview with Dr. Brenda Mitchell and Dr. Linda Stelly. The High School Journal, 90(2), 16-22.

Rasheed, A. (2006). Education in New Orleans: Some background. The High School Journal, 90(2), 4-7. https://doi.org/10.1353/hsj.2007.0005

Ravitch, D. (2013). Reign of error: The hoax of the privatization movement and the danger to America's public schools. New York, NY: Alfred A. Knopf.

Reckdahl, K. (2010, November 14). History's children: As the winds of change swirled around them five decades ago, three young girls, one black and two white, studied in isolation inside a 9th Ward school that became a tipping point in the nation's march toward desegregation. New Orleans Times-Picayune, p. A01.

Recovery School District (2010). $20104^{\text {th }}$ quarterly report prepared for the Louisiana Department of Education. New Orleans, LA.

Ritea, S., \& Nelson R. (2006, September 8). Milestone in urban education -The opening of ten Recovery District sites, a linchpin for a dizzying array of new public school options, went more smoothly than some predicted. New Orleans Times-Picayune, p. 01.

Rosselló Nevares, R. (2018, February 5). Puerto Rico governor Ricardo Rosselló Nevares' entire address to the nation. Elnuevodia. Retrieved from https://www.elnuevodia.com/english/english/nota/readgovernorrossellosmessageaboutato taleducationsystemreform-2396099/

Steinbeck, J. (1962). Travels with Charley: In search of America. New York, NY: Viking Press. Strachan, S. (2010). Ruby Bridges. New Orleans Magazine, 45(1), 26.

Straus, R. M., \& Lemieux, S. (2016). The two Browns: Policy implementation and the retrenchment of Brown v. Board of Education. New Political Science, 38(1), 44-60. https://doi.org/10.1080/07393148.2015.1125118 
Squires, G. D., \& Kubrin, C. E. (2005). Privileged places: Race, uneven development and the geography of opportunity in urban America. Urban Studies, 42(1), 47-68. https://doi.org/10.1080/0042098042000309694

The Problem We All Live With (1964, January 14). Norman Rockwell, oil of canvas, 36" x 58”. Story illustration for Look.

Thevenot, B. (2005, June 1). Five elementary schools to close - Middle schools might survive. New Orleans Times-Picayune, p. 01.

Thomas, P. L. (2013, May 17). Education reform in the new Jim Crow era. Truthout, no page. Time (1960, November 28). The South: D-day in New Orleans, Time, 76(22), 21.

U.S. Department of Education. (2017). Custom Reports. [State Tables Report: Achievement Data, State Test Data]. Available from the Ed.gov web site: https://eddataexpress.ed.gov

United States Courts. (2001). History - Brown v. Board of Education Re-enactment. Washington, DC: G.P.O.

U.S. Department of Education, National Center for Education Statistics (2003). Overview and Inventory of State Education Reforms: 1990 to 2000, NCES 2003-020, by David Hurst, Alexandra Tan, Anne Meek, and Jason Sellers. Project Officer: Edith McArthur. Washington, DC: 2003. Retrieved from https://nces.ed.gov/pubs2003/2003020.pdf

United Teachers of New Orleans (2006). 'National model' or flawed approach? The postKatrina New Orleans public schools. Retrieved from http://www.naomiklein.org/files/resources/pdfs/aft-nov-2006.pdf

Updike, J. (1960, December 10). Comment. The New Yorker, p. 43. Retrieved from https://www.newyorker.com/magazine/1960/12/10/comment-4710

Vaishnav, A., \& Alpert, B. (1999, November 19). Pupils get pass out of bad schools: Bill gives N.O. students options. New Orleans Times-Picayune, p. B1.

Vicens, A. J. (2018, March 28). Puerto Rico is trying to overhaul its public schools and teachers are furious. Mother Jones, Retrieved from https://www.motherjones.com/politics/2018/03/puerto-rico-is-trying-to-overhaul-itspublic-schools-and-teachers-are-furious/

Wells, A. E. (2004). Good neighbors? Distance, resistance, and desegregation in metropolitan New Orleans. Urban Education, 39(4), 408-427.

https://dx.doi.org/10.1177/0042085904265108

Whitehurst, G. J. (December 14, 2017). New evidence on school choice and racially segregated schools. Evidence Speaks Report, 2(33), 1-9. Retrieved from https://www.brookings.edu/wp-content/uploads/2017/12/whitehurst-report.pdf

Wieder, A. (1987). The New Orleans school crisis of 1960: Causes and consequences. Phylon, 48(2), 122-131.

Williams Walsh, M. (2017, May 16). How Puerto Rico is grappling with a debt crisis. The New York Times, Retrieved from https://www.nytimes.com/interactive/2017/business/dealbook/puerto-rico-debtbankruptcy.html 